\title{
Articles
}

\section{Extraction Equilibria and Solvent Sublation for Determination of Ultra Trace Bi(III), In(III) and Tl(III) in Water Samples by Ion-Pairs of Metal-2-Naphthoate Complexes and Tetrabutylammonium Ion}

\author{
Young-Sang Kim, ${ }^{*}$ Yoon-seok Choi, and Won Lee* \\ Department of Adranced haterial Chemisty, Norea Thiversin, Jochwon, Choongham 339-700, Korea \\ ${ }^{\dagger}$ Department of (hemisty, Kymghee Thiversin, Seoul 130-701, Korea \\ Received April 18,2002
}

\begin{abstract}
The solvent sublation using ion pairs of metal-2-naphthoate(2-HNph) and tetrabutyl ammonium (TBA ${ }^{+}$) ion has been studied for the concentration and determination of ultra trace Bi(III). In(III) and Tl(II) ions in water samples. The partition coeflicients $\left(K_{p}\right)$ and the estraction pereentages of 2 -HNph and the ion pairs to methyl isobutyl ketone (MIBK) nere obtained as hasic data. Alter the ion pair TBA $-\mathrm{M}(\mathrm{Nph})_{4}$ was lorned in water samples, the antaly les were coneentrated by the solvent sublation and the elements were detemined by GFAAS. The $\mathrm{pH}$ of the sample solution, the amount of the ligand and counter ion added and stirring time were optimised for the eflicient fomation of the ion pair. The type and amount of optimum surlactant, bubbling tine "lith nitrogen and the 1 pe ol solvent were investigated for the wolvent sublation as well. $10.0 \mathrm{mI}$, of $0.1 \mathrm{M} \mathrm{2-}$ $\mathrm{HN}$ h and $2.0 \mathrm{mI}$. of $0.1 \mathrm{M} \mathrm{TSA}^{+}$were added to a $1.0 \mathrm{I}$, sample solution at $\mathrm{pH} 5.0$. Alter $2.0 \mathrm{mI}$, ol $0.2 \%(\mathrm{w} / \mathrm{s})$ Triton X-100 was added, the ion pairs were extracled into $20.0 \mathrm{~mL}$. MIBK in a llotation cell by bubbling. The analy les were detemined by a calibration curve method with measured absorbances in MIBK, and the recovery Was $80-120 \%$.
\end{abstract}

Key Words : Solvent sublation, 2-Naphthoic acid, lon-pair formation, Solvent extraction, Flotation technique

\section{Introduction}

Following studies on the concentration and determination of trace elements by solvent extraction. ${ }^{1-3}$ flotation ${ }^{4.5}$ and solvent sublation ${ }^{\text {(is }}{ }^{\circ}$ in this laboratory, the solvent sublation using ion pairs of metal-2-naphthoate (2-HNph) and tetrabutyl ammonium (TBA) ion has been studied for the concentration and determination of ultra trace Bi(Ill), $\ln ($ Ill) and Tl(IIl) ions in water samples. Solvent sublation ${ }^{11}$ is a combined separation technique of solvent extraction ${ }^{12-1.5}$ and flotation. $^{16-2 ?}$

Usually organic ligands. which are well studied for this procedure of a high selectivity to analytical elements. have been used in this solvent sublation method. ${ }^{\text {fli }}$ lt is not easy to select an optimum ligand, but aliphatic carbosylic acids have been widely used as a ligand ${ }^{-7}$ Aromatic carboxylic acids have not been widely used because of their low extraction utility for metal complexes. ${ }^{15}$ Yamada and others ${ }^{2-}$ have studied the solvent extraction of $\mathrm{Co}(\mathrm{II}) . \mathrm{Ni}$ (II) and $\mathrm{Cu}(\mathrm{ll})$, using 1 -and 2-naphthoic acid as a ligand. Benzene or 1-octanol was used as a solvent. The partition coefficients and extraction constants of the ligands were obtained. and the analytical results of the ppt level of Mn(II) were reported by a catalytic method using several derivatives of the naphthoic acid synthesized. ${ }^{-4.2}$

Also the formation of ion pair was used to enhance the extraction efficiency by the synergistic effect. ${ }^{25-37}$ The complex ions became neutral. TBA' ion has been widely used for this purpose. Nasu et al. synergistically extracted thiocyanate complexes of $\mathrm{Cu}(\mathrm{I})$ and $\mathrm{Cu}(\mathrm{Il})^{26} \mathrm{Fe}(\mathrm{ll})$ and $\mathrm{Fe}(\mathrm{III})^{27}$ into chloroform. and $\mathrm{Cu}(\mathrm{II})$ into $\mathrm{MIBK}^{2 \times}$ by the formation of ion pair with TBA . Haiping et $\mathrm{al}^{3-1}$ studied the equilibrium on the extraction of $\mathrm{Li}(1)$ complex of water-soluble porphyrin by the formation of ion pair in the presence of TBA

ln the present work, the basic research was on the solvent sublation of $\mathrm{Bi}(\mathrm{Ill}), \mathrm{In}(\mathrm{III})$ and $\mathrm{Tl}(\mathrm{III})$, using 2-naphthoic $\operatorname{acid}(2-\mathrm{HNph})^{3.5}$ and TBA . The distribution ratio and extraction rate of the ion pair. $\mathrm{TBA}^{\prime} \cdot \mathrm{M}(\mathrm{Nph})_{1}{ }^{-}$were obtained as well as the distribution ratio of $2-\mathrm{HNph}$ between aqueous solution and MIBK. These basic data were utilized to optimize experimental conditions $(\mathrm{pH}$, the amount of ligand and counter ion. and so on) for the application of solvent sublation to the analysis of real samples (tap water. river water, etc.). The efficient flotation was also studied by investigating the effects of surfactants. such as Triton-X 100 . The applicability was exaluated with recoveries obtained from real samples

\section{Experimental Section}

Reagents and instruments. All reagents were analytical grade and the deionized water used was purified by Millipore Milli-Q water system. The standard solutions of 100 $\mu \mathrm{g} / \mathrm{mL}$ analytes were prepared with NIST reference material 
for $1 n(111)$ and KRISS references for Bi(lll) and Tl(1II) for the working standard solutions. The $0.1 \mathrm{M}$ solution of 2naphthoic acid was prepared in an ethanol with a guaranteedgrade reagent (Aldrich Co.) without further purification. A $0.2 \%(\mathrm{w} / \mathrm{y})$ ethanolic solution of Triton $\mathrm{X}-100$ was used as a surfactant.

A pH meter of Japan Tokyo Rikakikia Co. (Model PHM2000 ) was used with an lngold composite glass electrode. and it was adjusted with a buffer solution before use. The absorbances were measured with an atomic absorption spectrophotometer of Perkin-Elmer, Model 2380. equipped with HGA-400 programmer. The UV/Visible spectrophotometer was Slumadzu, Model UV 2100.

Partition coefficient of 2-naphthoic acid. A $1.0 \mathrm{~mL}$ of $1.435 \times 10^{-3} \mathrm{M} 2-\mathrm{HNph}$ was added to $100 \mathrm{~mL}$ of purified water, and the solution's $\mathrm{pH}$ was adjusted from 2.0 to 12.0 with $0.1 \mathrm{M} \mathrm{HNO}_{3}$ and $0.1 \mathrm{M} \mathrm{NaOH}$ solutions. The ligand was floated from the aqueous solution to $100 \mathrm{~mL}$ MIBK in a flotation cell by bubbling with nitrogen gas for 5 minutes. The plase was separated by 5 minutes standing, the remaining 2-HNph was measured with a UV/Visible spectrophotometer and the content was calculated by a standard calibration curve method to get the distribution ratio.

Distribution ratios of metal complexes and ion pairs. After the $\mathrm{pH}$ was adjusted to $5.0 \mathrm{in} 100 \mathrm{~mL}$ aqueous solution of given concentrations of analytical ions, 2-HNph 1.000 times the total metallic concentration was added. and this solution was stirred 5 minutes to form stable complexes. To form ion pairs. TBA 1.000 times each ion concentration was added, and the solution was stirred 5 minutes. This solution was transferred into a flotation cell to float the complexes and ion pairs by bubbling nitrogen gas 5 minutes. After 5 mimutes standing. the absorbances of the metal ions were measured in the aqueous solution to calculate distribution ratios with the concentrations of the remaining metal ions.

Solvent sublation. A $10.0 \mathrm{~mL}$ ethanolic solution of $0.1 \mathrm{M}$

Talsle 1. Instrumental conditions for Perkin-Flmer 2.380) (GF-AAS and heating programs for $\mathrm{H}(\mathrm{i} \wedge-400$ graphite funnace

\begin{tabular}{|c|c|c|c|}
\hline & $\mathrm{Bi}$ & In & $\mathrm{T} 1$ \\
\hline Wavelength (nm) & 223.1 & 303.9 & 276.8 \\
\hline Current $(m A)$ & 30 & .30 & 30 \\
\hline l3andwidth (m) & 0.7 & 0.7 & 0.7 \\
\hline Signal mode & & Absorbance & \\
\hline lnert gas & & Argon & \\
\hline Tube Type & & uncoaled lube & \\
\hline Drying ( $\mathrm{C}$ ) & $\begin{array}{c}110 \mathrm{C} \\
{[3 \mathrm{~s}] .(5 \mathrm{~s})}\end{array}$ & $\begin{array}{c}110 \mathrm{C} . \\
\lceil 3 \mathrm{~s}\rceil .(5 \mathrm{~s})\end{array}$ & $\begin{array}{r}110 \mathrm{C} \\
{[3 \mathrm{~s}] .(5 \mathrm{~s})}\end{array}$ \\
\hline Chaming ( $\mathrm{C}$ ) & $\begin{array}{r}400 \mathrm{C} \\
{[3 \mathrm{~s}](2 \mathrm{~s})}\end{array}$ & $\begin{array}{c}800: \mathrm{C} \\
\lceil 2 \mathrm{~s}\rceil .(10 \mathrm{~s})\end{array}$ & $\begin{array}{c}6000 \mathrm{C} \\
\lceil 3 \mathrm{~s}\rceil .(10 \mathrm{~s})\end{array}$ \\
\hline Atomization ( $\mathrm{C}$ ) & $\begin{array}{l}2300 \circ \mathrm{C} \\
\text { [3s]. (2s) }\end{array}$ & $\begin{array}{l}2400 \circ \mathrm{C} \\
33 \mathrm{~s}] .(3 \mathrm{~s})\end{array}$ & $\begin{array}{l}2300: \mathrm{C} \\
{[3 \mathrm{~s}] .(2 \mathrm{~s})}\end{array}$ \\
\hline Clcaning ( $\mathrm{C}$ ) & $\begin{array}{l}2600 \circ \mathrm{C} \\
\text { [3s]. (3s) }\end{array}$ & $\begin{array}{l}2600 \% \mathrm{C} \\
\lceil 3 \mathrm{~s}\rceil .(3 \mathrm{~s})\end{array}$ & $\begin{array}{l}2600 \mathrm{C} \\
{[3 \mathrm{~s}] .(3 \mathrm{~s})}\end{array}$ \\
\hline
\end{tabular}

Sample injection: $20 \mathrm{UI}$. (solvent: MJBK). [ ]: Holding Time. ( ): Ramping Time
2-HNph was added to $1.0 \mathrm{~L}$ of the filtered sample solution in an Erlemmeyer flask. and the $\mathrm{pH}$ was adjusted to 5.0 with $\mathrm{HNO}_{5}$ and stirred 5 minutes. $2.0 \mathrm{~mL}$ of the $0.1 \mathrm{M} \mathrm{TBA}^{\prime}$ ion and $2.0 \mathrm{~mL}$ of a $0.2 \%(\mathrm{w} / \mathrm{v})$ Triton $\mathrm{X}-100$ solution were combined by stirring 5 minutes. The solution was floated in a flotation cell by bubbling nitrogen gas at the rate of $30 \mathrm{~mL} /$ min for 5 minutes to extract the ion pairs into $20.0 \mathrm{~mL}$ MIBK. The concentration of analytical ions were deternined in the solvent directly by measuring absorbances with GF-AAS. The instrumental conditions of GF-AAS are shown as in Table $\mathrm{l}$.

\section{Results and Discussion}

Metal complexes and ion pairs. The $2-\mathrm{HNpl}^{3 / 1}$ reacts with three valent metal ions to form complex ions. And they form ion pairs with TBA as follows?

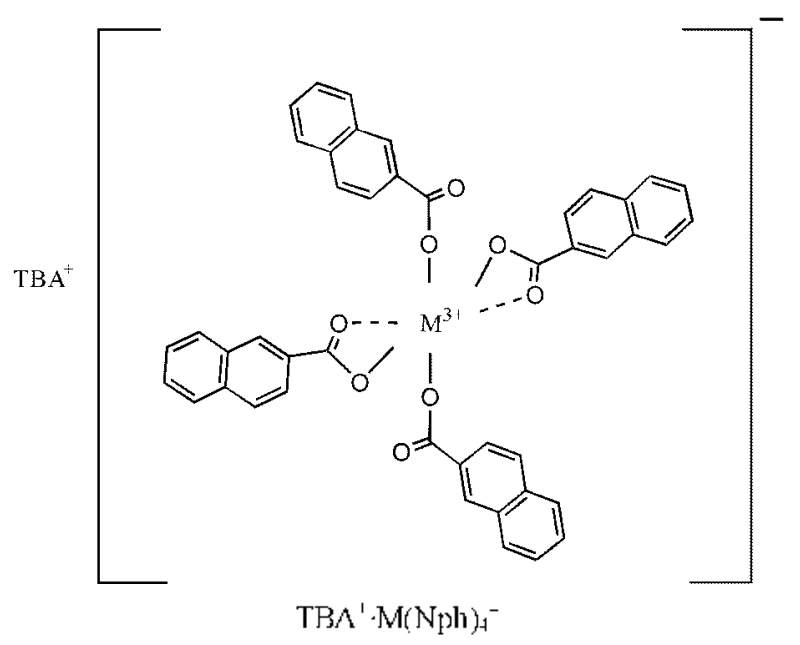

As shown in Figure 1, the absorption pattern of 2naphthoic acid is so different from the spectra of its metal complexes that the studies on the chemical behavior of the ligand and complexes were possible with UV/Visible spectra.

Partition coefficient of 2-naphthoic acid. The partition coefficient of 2-maphthoic acid between aqueous solution and MIBK solvent is indicated as follows:

$$
K_{\mathrm{p}}=\frac{\lceil\mathrm{HNph}\rceil_{a \mathrm{ge}}}{\lceil\mathrm{HNph}\rceil_{3 \mathrm{q}}}
$$

But the acid dissociation consiant $\left(K_{i i}\right)$ in an aqucous solution is

$$
K_{\mathrm{a}}=\frac{\left[\mathrm{H}^{+}\right\rceil_{\mathrm{acj}}\left[\mathrm{Nph}^{-}\right]_{\mathrm{aq}}}{[\mathrm{HNph}]_{\mathrm{al}}}
$$

and the value is $1.45 \times 10^{4}(298 \mathrm{~K})$. Therefore. a distribution ratio $\left(D_{1}\right)$ can be defined as follows ${ }^{28}$.

$$
D_{\mathrm{r}}=\frac{C_{\mathrm{ngy}}}{C_{\mathrm{aq}}}=\frac{[\mathrm{HNphl}]_{\mathrm{Mg}}}{[\mathrm{HNph}]_{\mathrm{aq}}+\left[\mathrm{Nph}^{-}\right\rceil_{\mathrm{aq}}}
$$



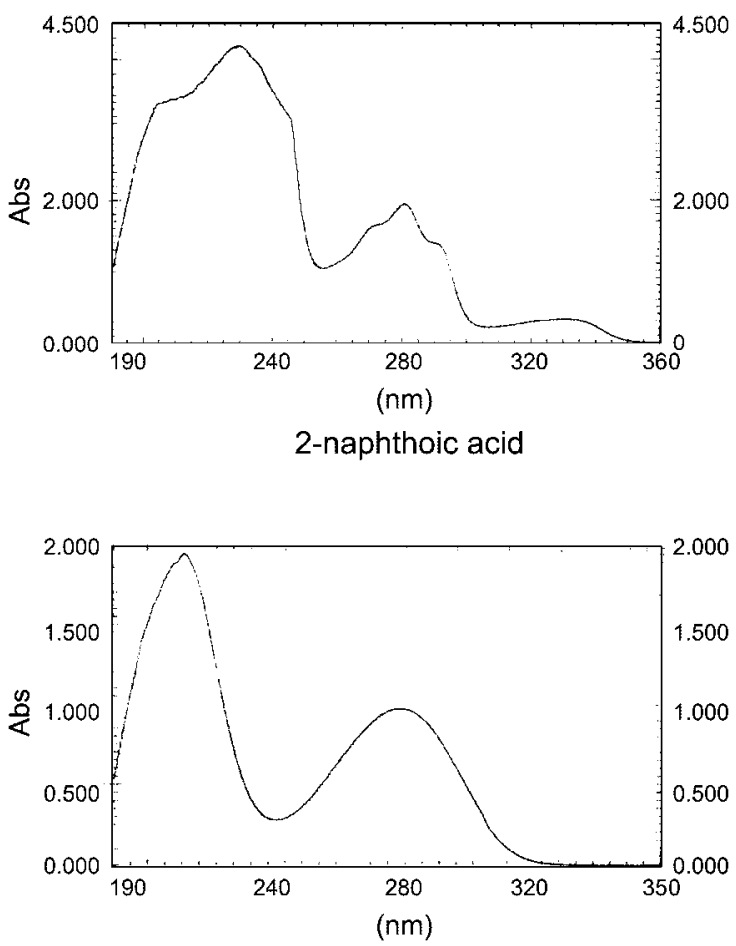

In (III)

Figure 1. The UJV/Vis spectra of 2-naphthoic acid and $\mathrm{M}-(\mathrm{N} p \mathrm{pl}) \mathrm{s}$

The distribution ratio of $2-\mathrm{HNph}$ between an aqueous solution and organic MIBK was calculated using UV/Vis absorbance of 2 -HNph remaining in the original aqueous solution and the equilibrated aqueous solution after an extraction. The values of distribution ratio were plotted from

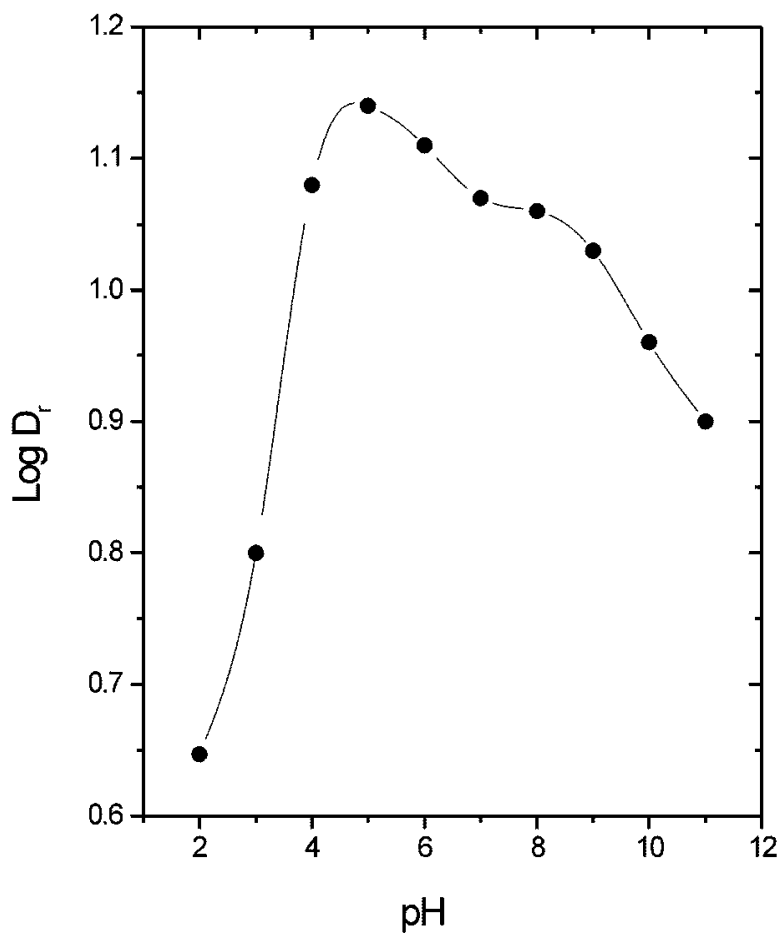

Figure 2. The effect of $\mathrm{p} H$ on the log $D_{1}$ of 2-naphthoic acid belwon aqueous solution and MIBK. $[2-\mathrm{H} \mathrm{INph}]=1.435 \times 10^{-6} \mathrm{M}$

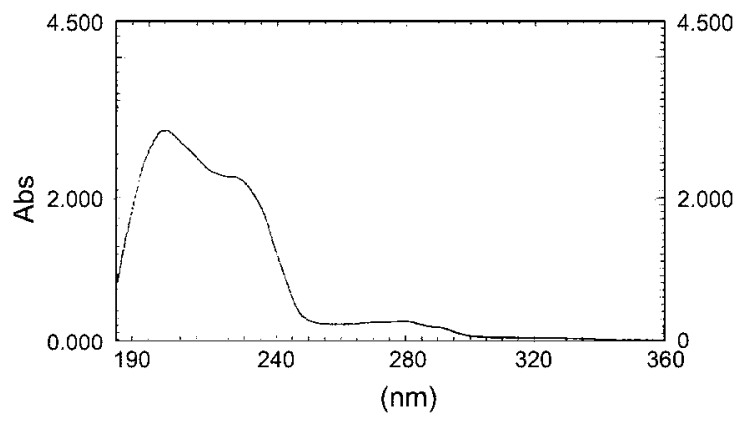

$\mathrm{Bi}(\mathrm{III})$

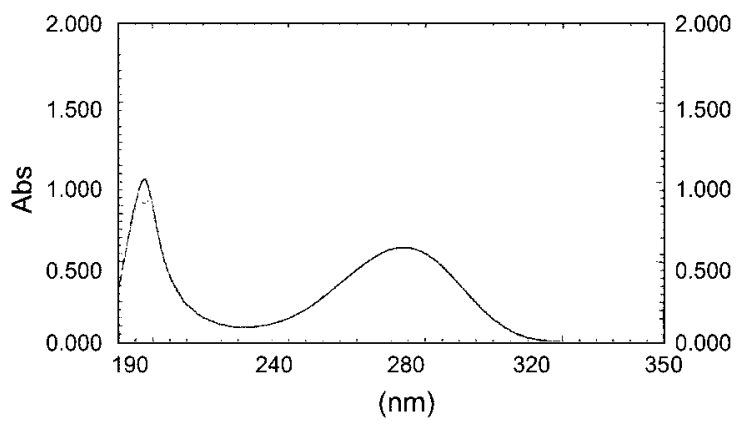

TI (III)

$\mathrm{pH} 2.0$ to 12.0 as shown Figure 2 .

Equation (3) was changed by the substitution of equations (1) and (2):

$$
\frac{1}{D_{\mathrm{r}}}=\frac{1}{K_{\mathrm{p}}^{-}}+\frac{K_{\mathrm{a}}}{K_{\mathrm{p}}\left[\mathrm{H}^{-}\right]}
$$

There are two ways to obtain the $K_{p}$ valuc. The reciprocal of the distribution ratio. $1 / D$, was plotted versus the reciprocal of lydrogen concentration. $1 /\left[\mathrm{H}^{-}\right]$. The $K_{\mathrm{p}}$, valuc can be calculated from the intercept and slope of the curce with a known value of the dissociation constant at $298 \mathrm{~K}$. The same $K_{p}$ valuc of $5.55 \times 10^{5}$ was obtained in this work.

Distribution ratio of metal complexes and ion pairs. 2Naphthoate (Nplı) ion reacts with a melal ion to form a complex in an aqueous solution and the complex is extracted into an organic solyent. such as MIBK. The reaction can be writicn as follows:

$$
\mathrm{M}_{(\mathrm{ag})}^{31}+3 \mathrm{Nph}_{(\mathrm{ag})}^{-}=\mathrm{M}(\mathrm{Nph})_{3(\mathrm{org})}
$$

(reaclion l)

The distribution ratio of the metal ion is indicaled as:

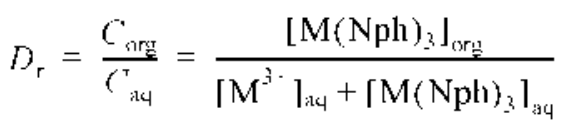

But $\left[\mathrm{M}(\mathrm{Nph})_{\dashv}^{-}\right]$anion is formed by the $\mathrm{Nph}^{-}$ion dissociated from some excess $2-\mathrm{HNph}$ in the aqueous solution. And it forms a ion pair of $\mathrm{TBA}^{\prime} \cdot \mathrm{M}(\mathrm{Nph})_{4}{ }^{-}$. with $\mathrm{TBA}^{-}$ion to be extracted into the organic solvent. 


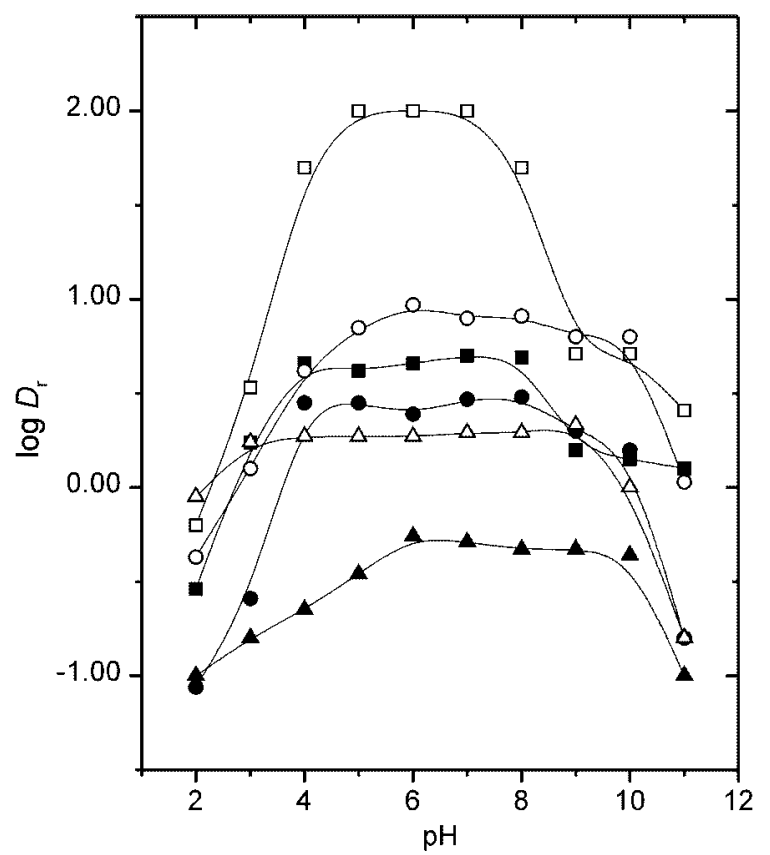

Figure 3. The effect of $1 \mathrm{H}$ on the distribution of metal-2naphthoate complexes and the ion pair's between aqueous solution

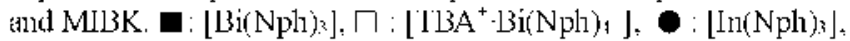

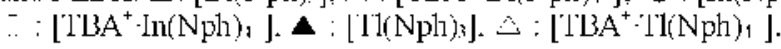

$$
\left.\mathrm{M}_{[a y\}}^{3-}+4 \mathrm{Nph}_{[a y\}}^{-}+\mathrm{TBA}_{(\mathrm{ity})}^{-}=\mathrm{IBA}^{+} \cdot \mathrm{M}(\mathrm{Nph})_{+}^{-}\right\rfloor_{(\mathrm{org} !}
$$

Therefore, the distribution ratio of the ion pair can be calculated as follow:

$$
\begin{aligned}
& D_{\mathrm{r}}=\frac{C_{\mathrm{org}}}{C_{\mathrm{aq}}} \\
& =\frac{\left[\mathrm{M}(\mathrm{Nph})_{3}\right]_{\mathrm{Brg}}+\left[\mathrm{TBA}^{-} \cdot \mathrm{M}(\mathrm{Nph})_{4}^{-}\right\rfloor_{\mathrm{prg}}}{\left[\mathrm{M}^{3 \cdot}\right\rfloor_{\mathrm{a} 4}+\left[\mathrm{M}(\mathrm{Nph})_{\xi}\right\rfloor_{\mathrm{aq}}+\left[\mathrm{TBA} \cdot \mathrm{M}(\mathrm{Nph})_{4}^{-}\right]_{\mathrm{aq}}}
\end{aligned}
$$

In Figure 3. the variation of the distribution ratio for the complexes and ion pairs at each $\mathrm{pH}$ of an aqueous solution is shown for the addition of TBA ion.

Extraction percentage of ion pairs. In general. an extraction percentage is indicated in the following equation $(7)^{33}$ :

$$
\mathrm{E}(\%)=100 \times\left[D_{\mathrm{r}} /\left(D_{\mathrm{r}}+\frac{V_{\mathrm{aq}}}{V_{\text {org }}}\right)\right]
$$

The extraction percentages of ion pairs at each solution $\mathrm{pH}$ according to this equation are given in Figure + for the addition of TBA $^{\prime}$ ion and no addition. The maximum extraction percentage was $100 \%$ for $\mathrm{Bi}(\mathrm{III})$ at $\mathrm{pH} 5-7.90 \%$ for $\ln (\mathrm{lll})$ at $\mathrm{pH} 6-7$ and $73 \%$ for $\mathrm{Tl}(\mathrm{III})$ at $\mathrm{pH} 6.0$. respectively: All of these values are much higher than values for the corresponding complexes.

Solution pH for the solvent sublation. Based on the above consideration of the extraction equilibria. the solvent sublation. which was the combined technique of flotation

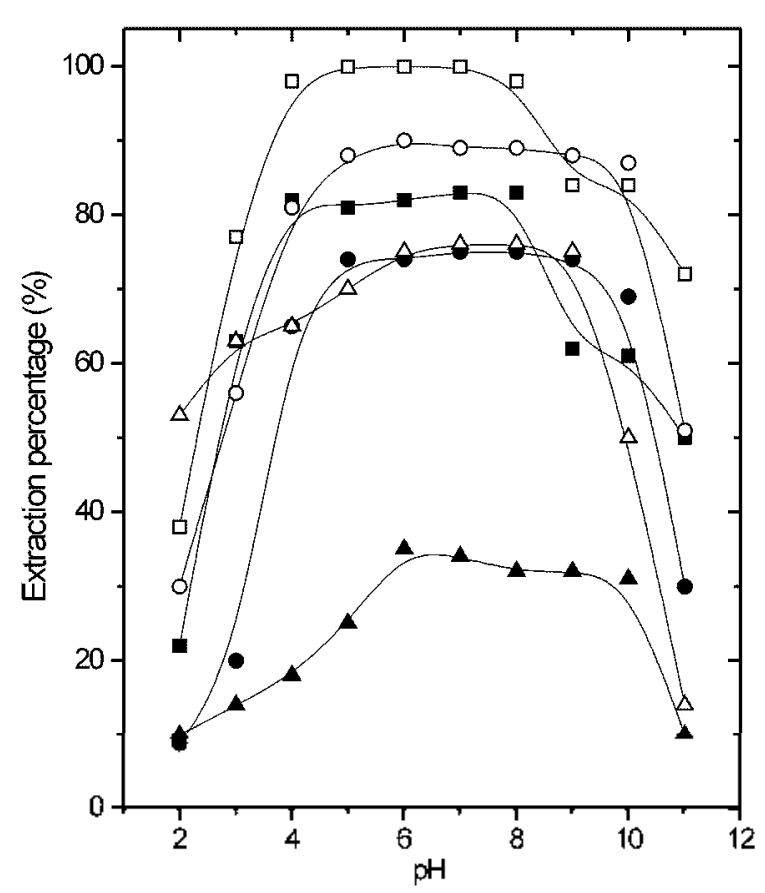

Figure 4 . The $\mathrm{pH}$ dependencies on extraction percentage of metal2-naphihoale and ion pairs from aculcous solution inlo MIBK.

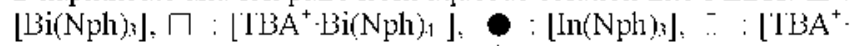

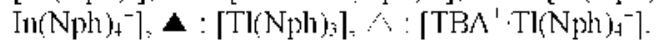

and solvent extraction. was applied to separate and concentrate Bi(lll), $\ln (\mathrm{Ill})$ and $\mathrm{Tl}(\mathrm{lll})$ in water samples for the determination. Various experimental conditions were investigated to fix an optimum procedure.

First. the $\mathrm{pH}$ was studied in an aqueous solution because 2-HNph should be ionized to 2-naphtoate( $\left.2-\mathrm{Nph}^{-}\right)$ion to form stable metal complexes..$^{37}$ The sublation efficiencies of three elements were investigated, changing the $\mathrm{pH}$ from 2.0 to 11.0 with the absorbances of the analytes in MIBK. The maximum absorbances appeared at a $\mathrm{pH}$ range of $4.0-6.0$ (Figure 5). The acid dissociation constant of $2-\mathrm{HNph}$ at $\mathrm{pH}$ 2.0-3.0 was very low with an $K_{\text {al }}$ of about $10^{-4}$. so the efficiencies decreased with increasing acidity. On the other hand. the efficiencies also decreased with increasing basicity, because the analy te ions usually formed insoluble hydroxide precipitate. Therefore. the $\mathrm{pH}$ was adjusted to 5.0 for further sublation.

Amount of ligand, 2-HNph. Usually, an excess of ligand is needed for the formation of metal complexes. The amount of $2-\mathrm{HNph}$ required to form stable metal complexes was investigated. The absorbances of analytes in MIBK were measured changing the adding volume of $0.1 \mathrm{M} 2-\mathrm{HNph}$ from 2.0 to $16.0 \mathrm{~mL}$ in the aqueous solution of $2.0 \mathrm{ng} / \mathrm{mL}$ of each metal ion. As shown in Figure 6, the absorbances plateaned on the addition of more than $10.0 \mathrm{~mL}$. which means more than 10,000 times in the mole ratio of analytes.

Type and amount of surfactant. A neutral TBA ion pair of complexes can be floated and extracted in MIBK. but a surfactant has been used to improve the flotation. This is due to the fact that a surfactant not only can support an ion pair by forming foams. but can also make the surface of the ion 


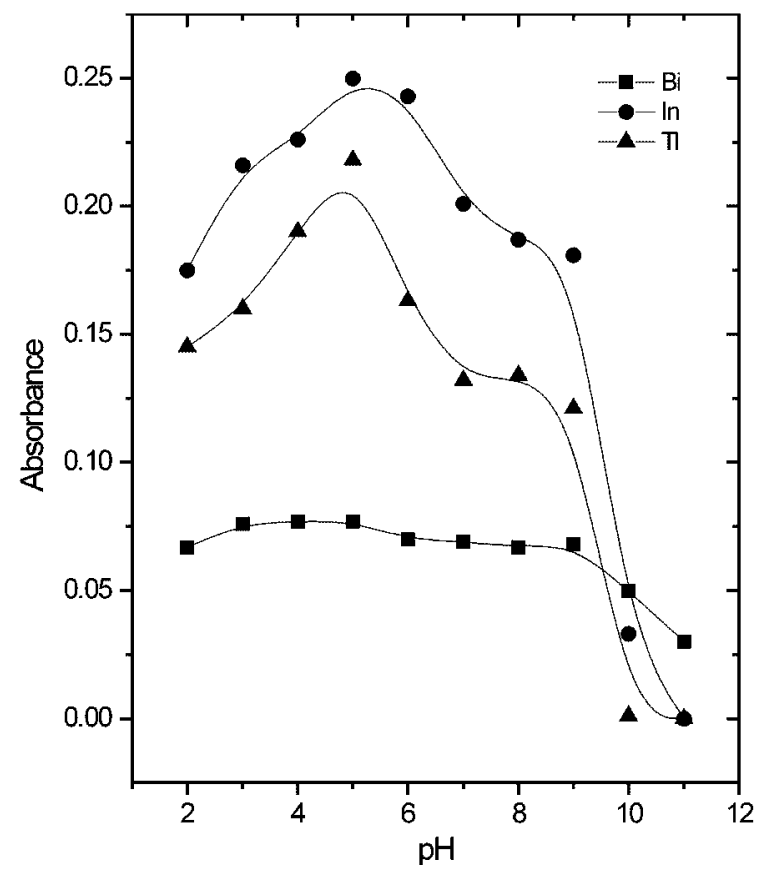

Figure 5. Lliect of pII on the complaxation of $2.0 \mathrm{ng} / \mathrm{mL}$ analy ions with 2-11aphthoic acid for an efficient solvent sublation.

pairs hỵdrophobic. ${ }^{1--x i}$

The flotation efficiencies of the ion pairs were investigated by the addition of the surfactants sodium oleate $(\mathrm{SO})^{1,18}$ and sodium lauryl sulfate (SLS) ${ }^{19,1)}$ as anionic surfactants. TX100 as a neutral one. and cetylpy ridinium chloride (CPC) as a positive surfactant. TX-100 indicated the best efficiency among the surfactants, as shown in Figure 7. Such a fact could be explained by the neutral structure of TBA'.

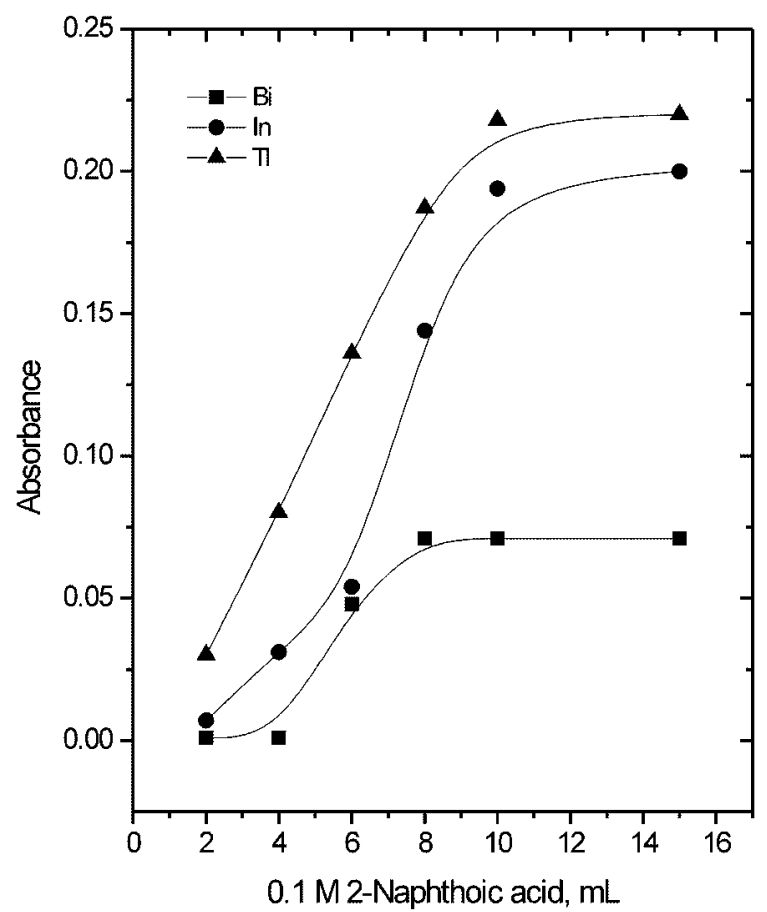

Figure 6. Amount of ligand to fonm the stable compleses for the effective solvent sublation of $2.0 \mathrm{ng} / \mathrm{mI}$, analy te ions

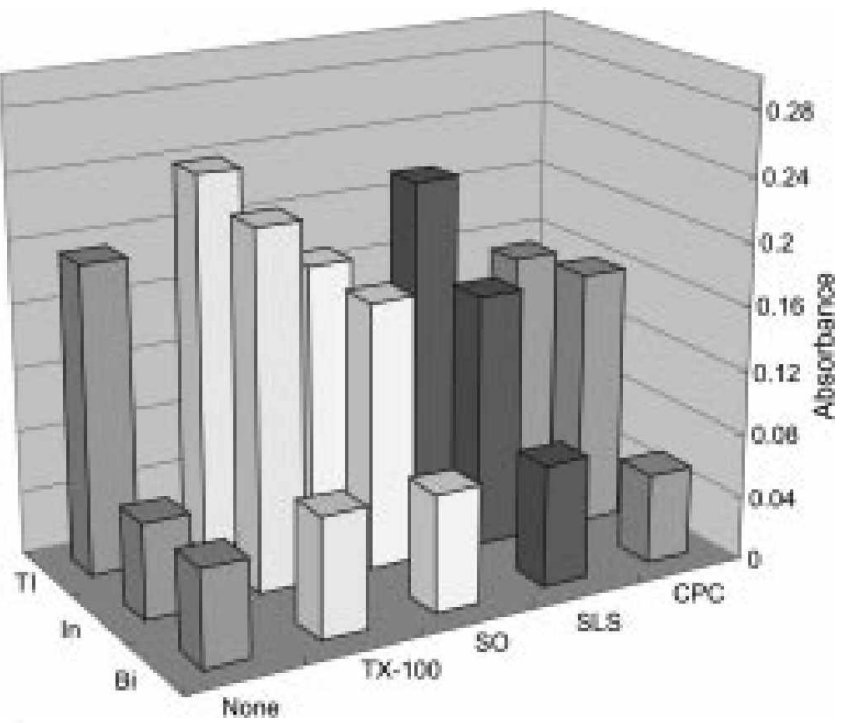

Figure 7. Comparison of tlotation etficiencies of $2.0 \mathrm{ng} / \mathrm{mI}$, according to various surlactants. IX-100; 'lriton X-100, CPC: celylpridinium chloride, SLS: sodium latuŗ] sullale, SO: sodium oleate.

$\mathrm{M}(\mathrm{Nph}){ }_{1}^{-}$by the addition of TBA' ion to $\mathrm{M}(\mathrm{Nph})_{4}{ }^{-}$solution. Bi(lll) was not greatly influenced by TX-100 compared with In(III) and Tl(III).

In general. the flotation is also influenced by the amount of surfactant. Therefore, a variation of absorbances was observed (in Figure 8 ) by changing the volume of $0.2 \% \mathrm{TX}$ 100 solution from 0.5 to $5.0 \mathrm{~mL}$. Bi(III) and $\ln (111)$ showed a plateau on the addition of more than $2.0 \mathrm{~mL}$ of $0.2 \% \mathrm{TX}-100$ solution. but the absorbance of Tl(lll) did plateau with more than $3.0 \mathrm{~mL}$ of $0.2 \% \mathrm{TX}-100$ solution. Therefore. $3.0 \mathrm{~mL}$ of

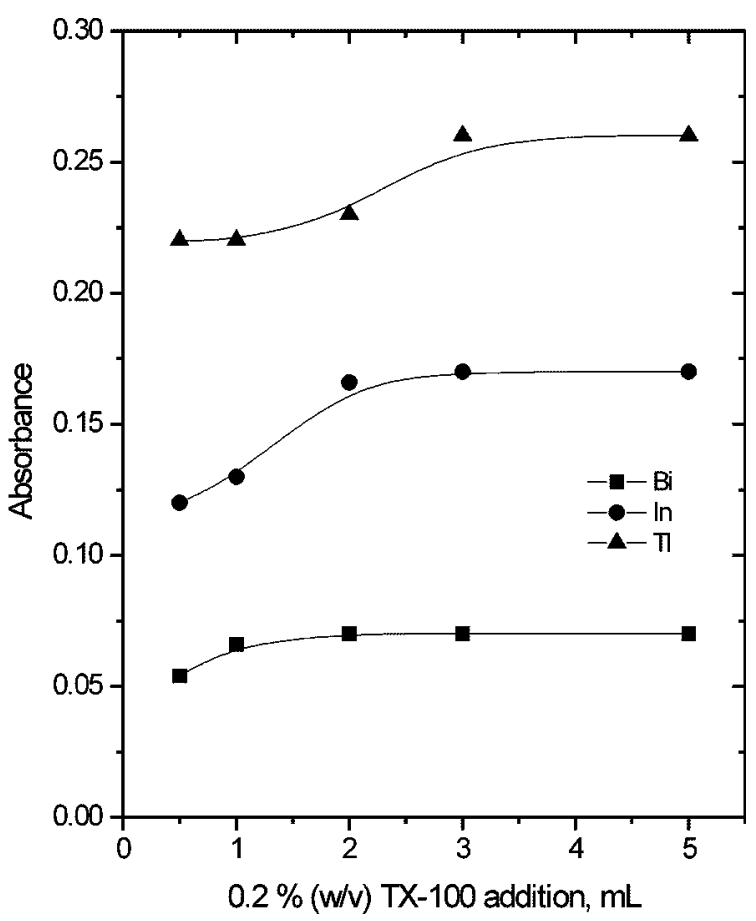

Figure 8. Amount of a surtactant tor the etfective sublation of ion pairs of $2.0 \mathrm{ng} / \mathrm{mI}$ analytes. 
$0.2 \% \mathrm{TX}-100$ was added in this experiment.

The solution should be stirred to promote the stable formation and efficient sublation of complexes after the addition of $\mathrm{TX}-100$. The optimum stirning time was investigated by the observation of absorbances, changing stirring time from 3 to 21 minutes. From the results, 5 minutes was fixed. but the absorbances of In(III) and Tl(IIl) were gradually decreased with the time. Such phenomena happened because $\mathrm{TBA}^{\prime} \cdot \mathrm{M}(\mathrm{Nph}){ }^{-}$ion pairs had partially weak positive charge. This made the hydrophilic properties stronger than the interfacial tension. which were overcame by the delayed stirring. The complex of Bi(III) was less influenced by stirring because this complex has a larger lyydrophilic property owe to the more intense neutral structure of $\mathrm{Bi}(\mathrm{Nph})_{3}$ compared with other ions.

Bubbling of $\mathbf{N}_{2}$ gas. In the flotation tecluuque, an inert gas is bubbled through a fritted porous glass disc from the bottom of the solution to float some precipitate. complex, ion pair. etc. Such floated materials are extracted into a light organic solvent in the solvent sublation techuique. Therefore. the bubbling velocity and time as well as the size of gas bubbles are very important to float and support materials on the surface of the solution. 89

After the bubbling velocity was fixed in this experiment. the bubbling time was investigated at the given velocity for efficient sublation to find the volume of the bubbling gas. Nitrogen gas was used because it is inert and inexpensive. The bubbling time was changed from 3 to 21 minutes to fix an optimum value (Figure 9). The absorbances of $\ln (111)$ and Tl(lll) were decreased by bubbling of more than 5 minutes. Such phenomena were due to the redistribution of ion pairs

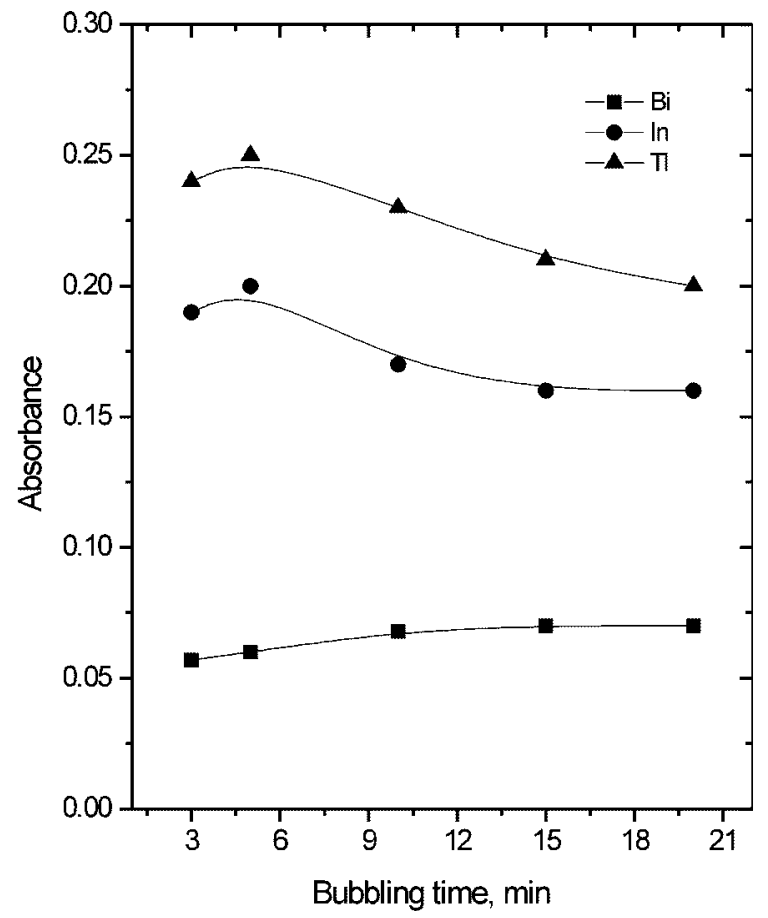

Figure 9. Bubbling time of a nitrogen gas for the elfective sublation of the jom paiss at the concentration of $2.0 \mathrm{ng} / \mathrm{mI}$.

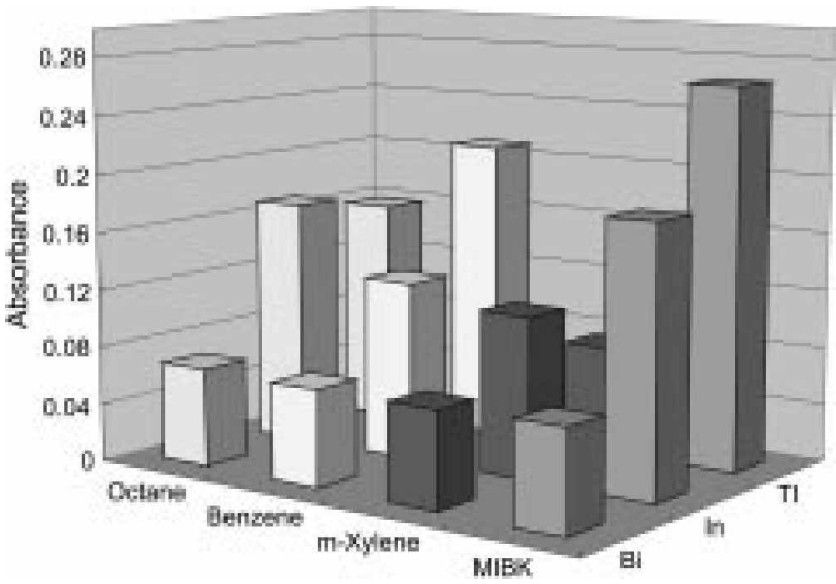

Figure 10. Sublation elliciencies for ion pairs of $2.0 \mathrm{ng} / \mathrm{mL}$ analy tes, according to the t $y$ pe of solvent.

coated with the surfactant. That is. the interface of gas-liquid on the $\mathrm{ML}^{-}{ }^{-} \mathrm{TBA}^{\prime}$ ion pair was broken by liquid-liquid face. Bi(lll) was only partially influenced by longer bubbling because the surface was already more hydrophobic than other ions.

Organic solvent. The partition of the floated material into a solvent is different according to type. ${ }^{9}$ lt depends on the affinity of the material to the solvent. Therefore. an optimum solvent should be found for the perfect partition of ion pairs. First of all, the solvent must be lighter than water because analy te material is floated and extracted into a solvent on an aqueous solution by a gas bubbling. And it must not interfere with the measurement of absorbance by AAS.

Benzene, $m$-xylene, MIBK and octane were used in this experiment. This was done under other optimum conditions. MIBK indicated the best absorbances for three kinds of analytes and is known to have the lowest background in the measurement of absorbance by a graphite fumace AAS. Therefore. MIBK was used as a solvent (Figure 10).

Analytical results. The optimized experimental conditions obtained above were applied to the analysis of real samples to investigate the usefulness of this procedure. A series of $1.0 \mathrm{~L}$ standard solutions for Bi(III). In(III) and Tl(III) were prepared. and given volumes of $0.1 \mathrm{M} 2-\mathrm{HNph}$. 0.1 M TBA ion and $0.2 \%(\mathrm{w} / \mathrm{v})$ Triton $\mathrm{X}-100$ were added to this $\mathrm{pH}$ adjusted solution with stirring. The ion pairs were sublated in a flotation cell to measure the absorbances in $20.0 \mathrm{~mL}$ MIBK. Calibration curves were prepared with these absorbances and concentrations (Figure 11 ).

Using these calibration curves. Bi(III). In(III) and $\mathrm{Tl}$ (III) were determined in real samples: tap water. Mihocheon water. Kobok reservoir water and edible mineral water. The given procedure in the experimental section was used for this and the results are given in Table 2 .

Recoveries were obtained with such real samples in which given amounts of analytes were spiked. The values are shown as $81-122 \%$. This procedure is considered to be applicable for the detennination of such trace elements in various kinds of water. 

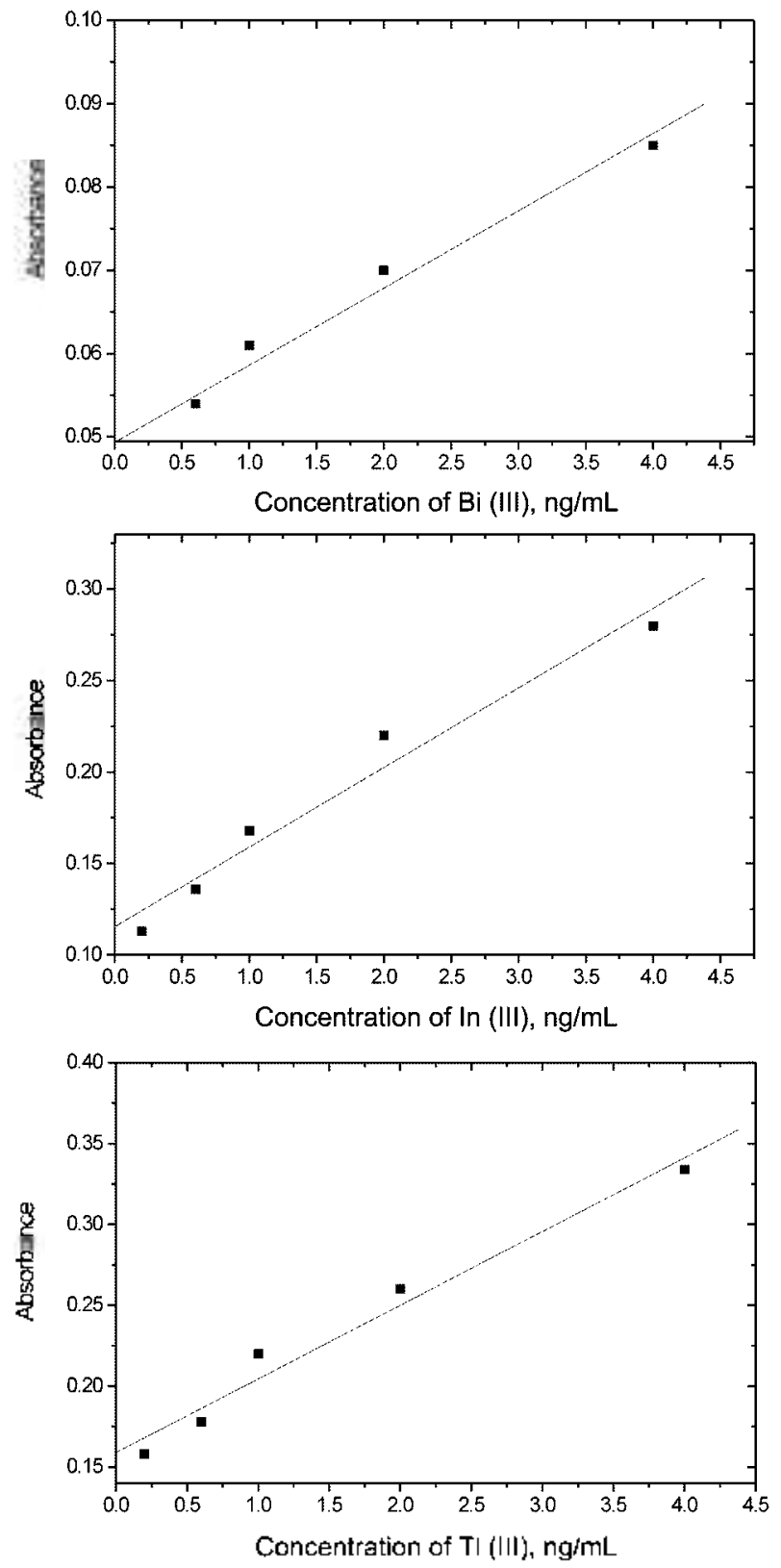

Figure 11. Calibration cures for the detenmination of analytes.

\section{Conclu sion}

Basic data of extraction equilibria. distribution ratio and extraction percentage. were obtained for the solvent sublation of trace $\mathrm{Bi}(\mathrm{III})$. In(III) and $\mathrm{Tl}(\mathrm{lll})$ as $\mathrm{TBA} \cdot \mathrm{M}(\mathrm{Nph})_{4}{ }^{-}$ ion pairs. These elements were determined in several kinds of water samples by a given procedure of optimized conditions.

1. The distribution ratio, $K_{1}$ of 2 -HNph between aqueous solution and MIBK was $5.55 \times 10^{5}$ at room temperature.

2. The extraction percentages of elements as an ion pair were $100 \%$ for $\mathrm{Bi}(\mathrm{IIl})$ at $\mathrm{pH} 5.0 .90 \%$ for $\operatorname{In}(\mathrm{III})$ at $\mathrm{pH} 6.0$ and $73 \%$ for $\mathrm{Tl}(\mathrm{III})$ at $\mathrm{pH} 6.0$.

3 . These three elements could be simultaneously concentrated by a solvent sublation at $\mathrm{pH} 5.0$. and a synergistic effect was obtained by the formation of the ion pairs.

Table 2. Analytical results of analytes in real samples by a solvent sublation (Unit : ng/mL)

\begin{tabular}{|c|c|c|c|c|c|c|}
\hline Sample & Elements & Spiked & Measured & Recovered & $\begin{array}{l}\text { RSI) } \\
\text { ("v) }\end{array}$ & $\begin{array}{c}\text { Recovery } \\
\left(0_{0}\right)\end{array}$ \\
\hline \multirow[t]{6}{*}{ lap water } & l3i(III) & 0.00 & 0.97 & & 3.09 & \\
\hline & & 200 & 3.25 & 2.28 & 0.87 & 109 \\
\hline & $\operatorname{In}(\mathrm{III})$ & 0.00 & 0.68 & 2.94 & & \\
\hline & & 200 & 3.07 & 2.39 & 0.04 & 115 \\
\hline & Tl(III) & 0.00 & 0000 & & & \\
\hline & & 200 & 2.32 & 2.32 & 2.15 & 116 \\
\hline \multirow{6}{*}{$\begin{array}{l}\text { "Miho- } \\
\text { cheon }\end{array}$} & $\mathrm{Bi}(\mathrm{III})$ & 0.00 & 0.00 & & & \\
\hline & & 200 & 1.98 & 1.98 & 1.52 & 99 \\
\hline & $\operatorname{In}(\mathrm{III})$ & 0.00 & 0.00 & & & \\
\hline & & 2.00 & 2.35 & 2.35 & 0.85 & 117 \\
\hline & $\mathrm{Tl}$ (III) & 0.00 & 1.56 & & 2.56 & \\
\hline & & 2.00 & 3.20 & 1.64 & 1.22 & 90 \\
\hline \multirow{6}{*}{$\begin{array}{l}\text { "Kobok } \\
\text { rescrvoir }\end{array}$} & $\mathrm{Bi}(\mathrm{III})$ & 0.00 & 0.97 & & 5.15 & \\
\hline & & 2.00 & 2.76 & 1.79 & 502 & 93 \\
\hline & $\operatorname{In}(\mathrm{III})$ & 000 & 0.75 & & 2.67 & \\
\hline & & 2.00 & 3.20 & 2.45 & 0.41 & 116 \\
\hline & $\mathrm{Tl}(\mathrm{III})$ & 0.00 & 0.57 & & 3.51 & \\
\hline & & 2.00 & 2.19 & 1.62 & 3.09 & 85 \\
\hline \multirow{6}{*}{$\begin{array}{l}\text { Mineral } \\
\text { water }\end{array}$} & l3i(III) & 0.001 & 0.00 & & & \\
\hline & & $20(x)$ & 2.23 & 2.23 & 1.34 & 111.5 \\
\hline & $\operatorname{In}(\mathrm{III})$ & 0.00 & 0.15 & & 6.67 & \\
\hline & & $20(x)$ & $2 . .34$ & 2.19 & 2.28 & 100 \\
\hline & $\mathrm{Tl}(\mathrm{III})$ & 0.00 & 0.00 & & & \\
\hline & & 2000 & 2.27 & 2.27 & 2.15 & 114 \\
\hline
\end{tabular}

"an irrigation reservoir around seochang campus of Korea Univ, "a riverside around scochang campus of Korea Unir:

4. A given procedure was applied to real water samples and recovery was $81-122 \%$.

Acknowledgment. This work was supported by grant No. 1999-1-124-3 from the Korea Science \& Engineering Foundation. The support is appreciated by authors.

\section{References}

1. Lee. I.-S.: Choi. J.-M.: Choi. H.-S.: Kim. Y. S. inal Sci \& Te'ch. 1996. 9(3). 221-234.

2. Choi. Y. S.: Choi. H.-S.: Kim. Y. S. Inal. Sci. de Tech 1997. 10(5). $370-377$.

3. Kim, Y. S.: Choi. Y. S.: In, G. Bull Korem Chem Soc 2000. $27(1) .137-140$.

4. Jung. Y. J.: Choi. J. M.: Choi. H. S.: Kim. Y. S. J. Konean ('hern. Soc 1996. $+0(12) .724-732$.

5. Kim. Y. S.: Kim. K. C.: Lee. C. W. Bull Korean Chent Soc. 1999. $20(4), 4.31-4.35$.

6. Kim, Y. S.: Shim, I. It.: Choi, Y. S.: I.ce. W.: I.ee, Y. I. Bull. Lorem Chem Soc 2001, 22, 19.

7. Kim. Y. S.: Shin. I. H.: Choi. Y. S.: Lee. W: Lee. Y. I. Nicroch'mical, J. 2001. 68.99.

8. Kim. Y. S.: Choi. Y. S.: Choi. H. S. Bull. Konem ('hem. Soc. 1998. 19. 10.36

9. Kim, Y. S.: Jung. Y. J.; Choi, U. S. Bull. Norem Chem Soc. 1998. 19.50.

10. Kim. Y. S.: Choi. Y. S.: Lee. W.: Lee. Y. I. Bnll Kon'on Chem. 
Soc. 2001. 22.821.

11. Kien ie1. A. I:a Jan. M. D.: P'arsons. J. R. inal Chem. 1995. 67. 4409.

12. Kawaguchi. I1.: Okamoto. T.: Miura. K.: Shimizu. T.: Shirakashi. T. Bull. Chom. Soc. Jpn. 1999. 72, 2445.

13. Noro, J. Anal. Sci. 1998, IH, 1099

14. Kawaguclii. H. Bumsehi Kagakn 2000. 49.801.

15. Watanabe. K.: Isomura. H.: Itagahi. M. Bmsehi Kagahu 2000. +9. 69) 1 .

16. Schulz. J. C.: Warr, G. C. Ind. Eng. Chtm. Re's. 1998, 37. 2807

17. Kabil, M. $\Lambda:$ All. M. A.: Khalifa. M. Г. Annl. Sci. 1999, 15,433

18. Aoyama, M.: IJobo. T.: Suzuki. S. Anal. Chim. Acta 1983, 153. 291.

19. Nakashima. S. Afral (hem. 1979. 51.654.

20. Cabezon. L. M.: Caballero. M.: Cela. R.: Perez-Bustanante. đ. A. Tolomla 1984, 31. 597.

21. Nakashima, S.: Yagi. M. Anal. Chim. deta 1984, 157. 187

22. Motomizu, S.: Oshima. M.: Nraki, K. Analist 1990. 15. 1627.

23. Vovee. D.: Leillin. H. . Hal. Chim. Acta 1974. 69. 27.

24. Zubareva. G. 1.: Adeev. S. M.: Radusher. A. V.: Gomzikor. A. I.: Zubares. M. P. Russ. J . 1ppl. (hem. 1998. 71. 124

25. Yamada. I1.; Matsui, Y.: Kuroki. Y.: Wada, I1. Anat Sci. 1997, 13. 237.
26. Walanabe. K.: Jahezawa. M.: Jagaki. M. Bunseki Kagaka 1996. 45.239.

27. Walanabe. K.: Tahahashi. S.: Itagah. M. Bunseki Kagaku 1996. 45,987

28. Nasu, A.: Yamauchi. S.: Sekine. T. And. Sci. 1997. 13.903.

29. Nasu, .; Takagi. I1.: Ohmiya. Y.; Sekine, T. Anal. Sci. 1999. 15. 177.

30. Nasu. A.: Yoshikana. A.: Noro. J.: Sekine. T. Lhal Sci. 1996. 2. 411.

31. Ohmisca, Y.: Sekine. T. Anal Sar, 1996. 12. 249.

32. Nasu, $\Lambda$ : Koji. K.: Sckine. T. Bull. Chem. Soc. Jpn. 1998. 71 . 2141

33. Yamameto. K.: Shimakawa T. Lnal. Sci. 2000. 16.641

34. Haiping. S.: Nishimoto. J.: Tabati. M. Lnal. Sci 1947. 13. 119

35. Mo. H.: Wang. A.: Wilkinson. I'. S.: P'ochapsky. T. C. J. im Chem. Soc 1997. 119.11666.

36. Blackburtn. A. C.: Fitzgerald, I.. J.: Gerkin, R. F. Acta Cnust 1996. 52.2862

37. Sekine 1.: Kobelowa. 1.: Noro. J.: Dung. N. T. K. Anat. Sci 1994. 10. 743 .

38. Choi. Y. S.: Choi. H. S.: Kim. Y. S. J. Korem Chem Soc 1998. fI. 36 . 